\title{
GERENCIAMENTO DE RESÍDUOS SEMISSÓLIDOS: UM ESTUDO PARA O LABORATÓRIO DE FIXAÇÃO BIOLÓGICA DO NITROGÊNIO
}

\author{
Silviane Barra Ferreira \\ MBA em Pericia, Auditoria e Gestão Ambiental \\ Aline Guimarães Monteiro Trigo \\ Instituto Federal do Rio de Janeiro/IFRJ \\ Josimar Ribeiro de Almeida \\ Escola Politécnica/UFRJ e Instituto de Química/UERJ
}

\section{RESUMO}

O presente trabalho tem como objetivo demonstrar a importância do gerenciamento de resíduos dentro do Laboratório de Fixação Biológica do Nitrogênio (LFBN). Essa iniciativa surgiu no momento em que se verificou que o volume de resíduos semissólidos e sólidos gerados na rotina do laboratório havia aumentado em muito. Para isso, adotou-se o Programa Interno de Gerenciamento de Resíduos (PIGR), que é composto pelas seguintes ações: a não geração, a minimização da geração, a reutilização, a reciclagem, o tratamento e a disposição final. Verifica-se que a gestão de resíduos é uma prática desafiadora. Os resíduos gerados no interior do laboratório, dentre eles os meios de cultura, e materiais sólidos diversos, se não forem bem tratados e destinados de forma adequada podem ser um problema para o meio ambiente ou se bem gerenciado pode ser uma oportunidade para a diminuição dos custos de produção e dos riscos ambientais. Uma apropriada gestão de resíduos pode representar melhoria na imagem do laboratório, adequando-se aos moldes politicamente corretos. Assim, o que é resíduo de uma atividade passa a ser insumo de outra.

Palavras-chave: Resíduos de laboratório, Gerenciamento.

\begin{abstract}
This work aims to demonstrate the importance of waste management within the Biological nitrogen fixation Laboratory (LFBN). This initiative arose when it was found that the volume of solid waste generated in the semissólidos and routine laboratory had increased greatly. To do this, it took the Internal Programme management of waste (PIGR), which consists of the following actions: not generation, the generation minimization, re-use, recycling, treatment and final disposal. It turns out that waste management is a challenging practice. Waste generated within the lab, among them the culture media, and various solid materials, if they are not well treated and intended for appropriately can be a problem for the environment or if managed well can be an opportunity for lower production costs and environmental risks. An appropriate waste management can represent improvements in the image of the laboratory, adapting to templates politically correct. So, what is the residue of an activity becomes input of another.
\end{abstract}

Key-Works: waste, management, Laboratory

\section{INTRODUÇÃO}


$\mathrm{Na}$ atualidade, o volume de lixo com que a humanidade convive é resultado dos padrões culturais impostos pela sociedade. Assim, cada vez são produzidas maiores quantidades de resíduos e cresce também a complexidade da sua composição, com o consequente aumento dos impactos da sua destinação (ALMEIDA, 2010).

Há uma grande geração de produtos e suas embalagens que não são descartados de maneira correta. Muitos lugares, indústrias, laboratórios e outros departamentos não sabem ao certo como descartar as sobras ou restos e muitas vezes rejeitam em lugares incorretos sem a menor preocupação. Os resíduos semissólidos gerados em um laboratório, como os meios de cultura, são classificados, segundo a ABNT;NBR 10.004/2004 na classe IIA, pois não apresentam nenhuma toxicidade ou patogenicidade ${ }^{1}$.

Baseado na preocupação com o meio ambiente, e com as exigências de novas legislações, está ocorrendo à busca de novos processos de gerenciamento, através da implementação de ferramentas que amenize ou põe fim ao descarte de produtos no meio ambiente. Atualmente, as pessoas estão cada vez mais exigentes quanto ao consumo de produtos que não degradem e nem deteriorem o meio ambiente. Para isso é exigida uma adequação a nova situação e uma produção de serviços/produtos politicamente corretos, ou seja, que não causem impactos ao meio ambiente ou causem o mínimo impacto possível.

Portanto, esse trabalho tem como objetivo demonstrar a importância do gerenciamento dos resíduos que são gerados nos trabalhos de rotina do Laboratório de Fixação Biológica do Nitrogênio (LFBN), para atender um manejo adequado e buscar implementação de procedimentos de acordo com as Normas de Gestão da Qualidade.

\section{O Laboratório de Fixação Biológica do Nitrogênio: caracterização, função e manejo dos resíduos gerados}

\footnotetext{
${ }^{1}$ Os microrganismos inoculados nos meios de cultura são bactérias de solo com capacidade de fixar o nitrogênio atmosférico em associação com raízes de plantas leguminosas sendo, portanto um material biológico composto de organismos benéficos à agricultura, exclusivamente fixadores de nitrogênio que são isentos de agentes fitotóxicos, patogênicos ao homem, animais e plantas, assim como metais pesados e agentes poluentes.
} 
O LFBN é um dos laboratórios da Fundação Estadual de Pesquisa Agropecuária (FEPAGRO) e está, localizado junto à sede da mesma, em Porto Alegre, desenvolvendo trabalhos de pesquisa, prestação de serviços e produção. Possui o banco referência nacional Coleção de Culturas de Rizóbio SEMIA ${ }^{2}$ para elaboração de produtos inoculantes comerciais, as quais são fornecidas para a indústria nacional e internacional anualmente, de acordo com a legislação brasileira vigente. O Centro de Recursos Microbiológicos (MIRCEN) ${ }^{3}$ proporcionou uma ampliação da prestação de serviços por parte do laboratório tais como: 1) depósito de estirpes isoladas de outras instituições; 2) depósito de estirpes eficientes para inoculação de leguminosas, recomendadas em reuniões de rizobiologistas de instituições de pesquisa do país, componentes da RELARE ${ }^{4}$; 3) centro para teste e distribuição de culturas de estirpes recomendadas para indústria de produtos inoculantes; 4) fornecimento de estirpes solicitadas por instituições de pesquisa e indústrias nacionais e internacionais.

O LFBN é, também, o único laboratório credenciado pelo MAPA, no Brasil, para executar as análises do controle fiscal e pericial da qualidade dos produtos inoculantes nacionais e dos importados a serem comercializados no território nacional, realizando este serviço desde 1975. Além disto, desde sua criação em 1950, o LFBN tem realizado pesquisas na área da fixação biológica do nitrogênio, treinamento de recursos humanos e produção de produtos inoculantes para atender a demanda de pesquisa, ensino e extensão rural.

Os resíduos semissólidos são advindos dos meios de cultura que são empregados para observar a manifestação do crescimento bacteriano para utilização nas diferentes atividades executadas no laboratório. Há uma demanda muito grande, ocorrendo uma transformação na metodologia de descarte. Além desses resíduos, também, são gerados resíduos sólidos originados de inoculantes turfosos, vidrarias,

\footnotetext{
${ }^{2}$ É o um acervo em torno de 1200 estirpes de rizóbio indicadas para cerca de 200 plantas leguminosas de interesse econômico, sendo que 139 dessas estirpes são autorizadas pelo Ministério da Agricultura, Pecuária e Abastecimento (MAPA.).

${ }^{3}$ Centro de Recursos Microbiológicos que desde 1978, anexou à coleção SEMIA e criou em convênio com o Estado do Rio grande do Sul em conjunto com a UNESCO, colaboração com FAO e a Organização Internacional de Pesquisa Celular (ICRO), estabelecido no antigo IPAGRO (Instituto de Pesquisas Agronômicas).

${ }^{4}$ Rede de Laboratórios para Recomendação e Difusão da Tecnologia de Inoculantes Microbianos de Interesse Agrícola
} 
materiais plásticos e papéis assim como resíduos líquidos provenientes de soluções e de produtos inoculantes líquidos.

Desde o início da década de 90, os técnicos e pesquisadores que trabalham no laboratório, vêm desenvolvendo metodologias sobre o aproveitamento e manejo de materiais, bem como a reciclagem dos mesmos usados na rotina. Essa consciência vem sendo repassada para todos que trabalham no laboratório, desde funcionários efetivos, estagiários, bolsistas até o pessoal de limpeza.

Quanto aos resíduos sólidos, como as embalagens plásticas e de papel, vidrarias quebradas e materiais plásticos presentes na rotina laboratorial, estes são descartados em sacos próprios para o resíduo seco e são colocados na calçada, nos dias indicados para esse tipo de coleta, em frente à sede da Fepagro. Esse resíduo é recolhido por cooperativas, conforme descrito no capitulo III da Lei complementar nํ. 234 - Limpeza Urbana do Município de Porto Alegre.

Os produtos inoculantes líquidos e sólidos são doados a agricultores interessados que utilizam como fertilizantes em pequenas plantações hortifrutigranjeiras, conforme descrito no capítulo III seção II art. 36 alínea V, Lei no. 12.305/2010 Política Nacional de Resíduos: "implantar sistema de compostagem para resíduos sólidos orgânicos e articular com os agentes econômicos e sociais formas de utilização do composto produzido".

\section{METODOLOGIA}

Uma das ferramentas utilizadas foi elaboração das Boas Práticas de Laboratório (BPL) com a descrição através dos Procedimentos Operacionais Padrão (POP), Instruções de Uso (IUs) para equipamentos e Formulários (FOR) para diversos registros. O LFBN tem como objetivo a implantação da Norma ISO 17.025, para se adequar ao sistema de qualidade e a legislação vigente.

A metodologia adotada para a implantação de gerenciamento de resíduos dentro do laboratório vem ao encontro da ação: "minimizar a geração de resíduos”. Para tanto, três princípios serão incorporados no Programa de Gerenciamento Interno de Resíduos (PGIR): reduzir, reutilizar e reciclar. Também denominada de política ecologicamente correta dos 3 R-s. 
Segundo Oliveira (2000, p. 237), a Política Nacional de Gestão de Resíduos Sólidos tem como objetivos: a defesa ambiental e da saúde pública, a partir do fomento entre as cidades brasileiras de um sistema integrado de gestão, tendo como princípios:

$$
\begin{aligned}
& \text { I - a não geração de resíduos; } \\
& \text { II - a minimização da geração; } \\
& \text { III - a reutilização; } \\
& \text { IV - a reciclagem; } \\
& \text { V - o tratamento; } \\
& \text { VI - a disposição final. }
\end{aligned}
$$

O Estado do Rio Grande do Sul foi o primeiro em todo o Brasil a criar e estabelecer localmente uma política de gerenciamento de resíduos sólidos, definida pela Lei № 9.921 de 27 de julho de 1993. Nela, entre outras determinações, estabeleceu de forma clara, transparente e objetiva que os estabelecimentos industriais, comerciais, e de prestação de serviços, incluindo os de saúde que gerarem seu próprio resíduo sólido sejam responsáveis pela coleta, tratamento, transporte, processamento e destinação final do mesmo, independentemente da contratação de terceiros para a execução do serviço, atue ele na esfera pública ou na esfera privada, tendo seu destino os denominados "Aterros Sanitários", que na verdade são verdadeiros lixões a céu aberto.

Como descrito no art. 8으 pela lei ํ․ 9.921/93

A coleta, o transporte, o tratamento, o processamento e a destinação final dos resíduos sólidos de estabelecimentos industriais, comerciais e de prestação de serviços, inclusive de saúde, são de responsabilidade da fonte geradora, independentemente da contratação de terceiros, de direito público ou privado, para execução de uma ou mais dessas atividades.

Assim sendo, a definição precisa e objetiva da responsabilidade da fonte geradora é de quem gera os resíduos, sejam estabelecimentos industriais, comerciais, prestadores de serviços, laboratórios e inclusive da área de saúde, sem dúvida nenhuma acaba de vez com as incertezas existentes dando uma solução definitiva para essa questão bastante controvertida.

O gerenciamento de resíduos gerados dentro do LFBN iniciou-se pela separação de resíduos sólidos, onde o objetivo principal não é simplesmente reduzir a quantidade de resíduos produzidos no laboratório a qualquer custo, mas acima de tudo criar 
uma cultura organizacional de segurança e de não desperdício. A segregação é importante porque permite que se adote um manuseio, embalagem, tratamento mais adequados aos riscos oferecidos por um determinado tipo de resíduo, permitindo que se intensifiquem as medidas de segurança apenas quando realmente necessário.

No Município de Porto Alegre, esse processo de separação de resíduos ou coleta seletiva começou a ser desenvolvido quando houve uma maior preocupação com a geração desses em conjunto com o DMLU ${ }^{5}$. A coleta seletiva de resíduos tornou-se de extrema importância para a sociedade. Além de gerar renda para milhões de pessoas e economia para as empresas, também significa uma grande vantagem para o meio ambiente uma vez que diminui a poluição dos solos e rios.

Após um curso oferecido aos funcionários acerca do gerenciamento e descarte de resíduos em laboratório, o processo de segregação dos resíduos e da rotulagem dos recipientes (Figura $1 \mathrm{a} \mathrm{e}$ b) foi intensificado. Os recipientes foram rotulados, como: materiais orgânicos, recicláveis, utensílios perfuro cortantes e vidros. Esse processo de rotulagem facilitou a identificação, no momento de recolhimento, tanto para os funcionários que exercem a função de limpeza, bem como para os demais da unidade.
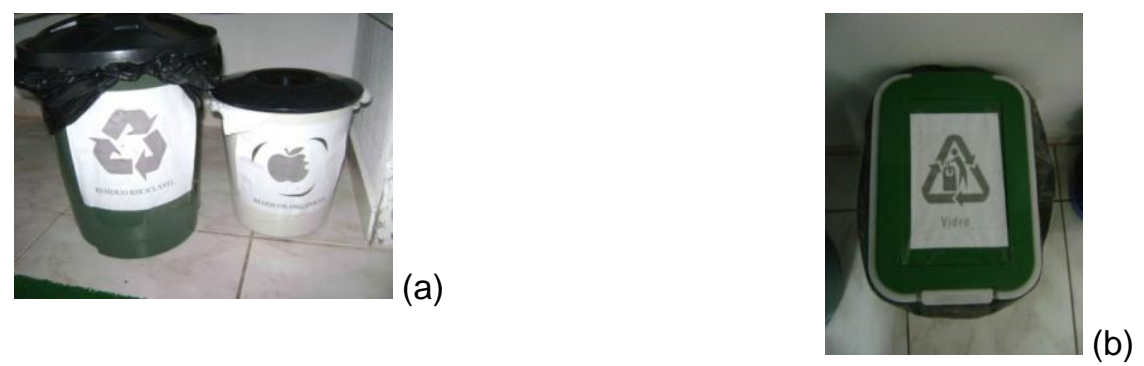

Figura 1- Recipientes rotulados conforme a devida segregação dos resíduos (a) resíduos recicláveis; (b) resíduos perfuro cortantes e vidros

Quanto à reutilização/reaproveitamento, é um método de gerenciamento de resíduos baseado no emprego direto de um produto com a mesma finalidade para qual a foi originalmente concebido. O reaproveitamento de embalagens plásticas, como aquelas de potes de requeijão, que após a devida assepsia, são utilizadas para

\footnotetext{
${ }^{5}$ Departamento Municipal de Limpeza Urbana
} 
armazenamento de ponteiras (tips) de pipetas automáticas (micropipetadores), tampas de borrachas e plásticas. A reutilização de embalagens plásticas é uma inovação desde o ano 2002. Essa foi uma das maneiras encontradas para utilização de utensílios que fossem reaproveitadas. Os recipientes anteriores eram frascos de vidro provenientes de conservas e compotas de alimentos e ainda são utilizados.

Embalagens plásticas de produtos achocolatados (Figura 2), após serem bem higienizadas, servem para colocar tampas plásticas para tubos de ensaio de vidro, utilizadas nas diluições seriadas em análises de inoculantes.

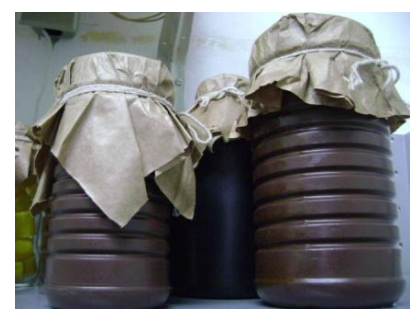

Figura 2 - Embalagens plásticas de produtos achocolatados

Frascos de vidro de diversos tamanhos (Figura 3) são utilizados para colocar tampas plásticas e seringas descartáveis que são reaproveitadas. As seringas plásticas são reutilizadas, após higienização e esterilização em autoclave.

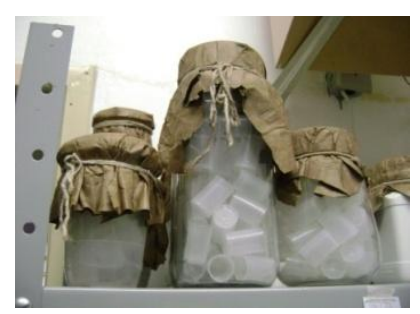

Figura 3 - Recipientes de vidro com tampas de plástico

Os tips (Figura 4) e tubos eppendorfs (Figura 5) são feitos de material plástico resistente à esterilização, em autoclave, e também são reutilizados até que sua vida útil permita.

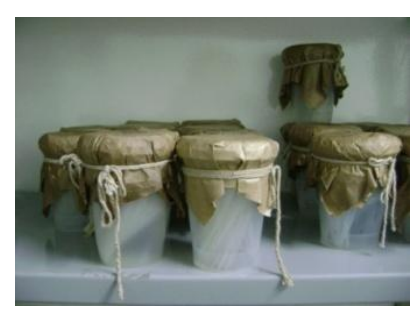

Figura 4 - Tips esterilizados armazenados em copos de requeijão 


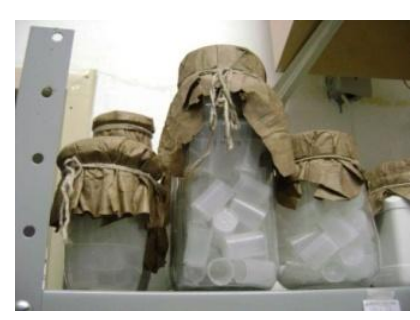

Figura 5 - Tubos eppendorfs esterilizados e armazenados em potes de requeijão e de vidro

Portanto, a reutilização é um método de controle útil na minimização da produção de resíduos, mantendo-os bem envolvidos com as suas características e funções originais. Assim, as atividades de redução na fonte influenciam o fluxo do resíduo, antes do ponto de geração. Além de aumentar a vida útil do produto, o reuso de produtos e materiais retardam o tempo que os itens devem ser finalmente descartados como resíduos.

As garrafas de refrigerante PET (Politereftalato de Etileno), (Figura 6 a) após serem lavadas com água e sabão são reutilizadas para acondicionamento de ponteiras (tips) que estão avariadas (por exemplo, ponta amassada). Esse acondicionamento dos tips tem como objetivo, além da retirada do material inapropriado para a rotina laboratorial, a proteção das pessoas que coletam o lixo, pois visam à segurança por serem materiais contundentes. No caso de trabalhos com agentes contaminantes, estas garrafas contendo os tips são autoclavadas (Figura 6 b) antes do descarte na coleta seletiva.
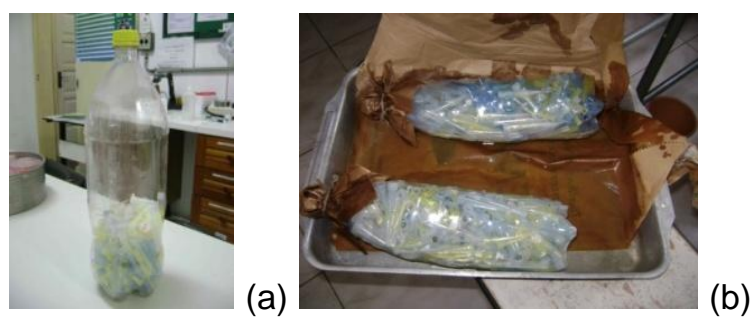

Figura 6 - Tips acondicionados em garrafas PET (a) antes e (b) após o processo de esterilização A indisponibilidade de recursos é um motivo de inquietação e preocupações atualmente. A cada dia, os recursos, dito renováveis, como a água, tornam-se de mais difícil acesso. O reuso da água é um processo pelo qual a água tratada ou não é reutilizada para o mesmo fim ou outro fim. Por essa definição, foi adotado o reuso da água de lavagem de ponteiras, que é misturada com Hipoclorito de Sódio 0,1\%, 
pois além ser de econômica é também uma maneira de poupar o ambiente. $O$ reuso é uma prática constante. $O$ processo ocorre da seguinte maneira: as ponteiras após o uso ficam mergulhadas nessa solução por 24 horas. Após esse tempo são escorridas, com auxílio de peneiras e um funil, e vertida para bombonas (Figura 7). Esta água fica armazenada para o seu reaproveitamento.

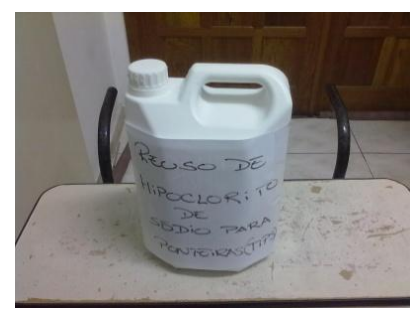

Figura 7 - Bombona onde é armazenada a água de reuso para lavagem de tips

Outra maneira de economia é o reuso do detergente Extran, que é utilizado para a lavagem dos tips. Estes são escorridos, com auxílio de uma peneira, e todo o detergente é armazena em frascos (Figura 8) para reaproveitamento em demais lavagens.

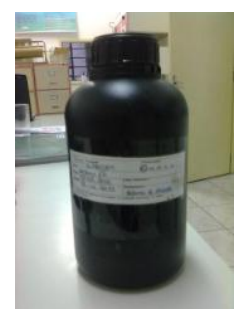

Figura 8 - Frasco de detergente Extran com rotulagem contendo data produção e a data de validade

\section{Tratamento de resíduos semissólidos}

Foi adotado um sistema de manejo dos resíduos semissólidos, que é constituído pelas seguintes etapas:

a) Geração: os meios de cultura consistem na associação qualitativa e quantitativa de substâncias que fornecem os nutrientes necessários ao desenvolvimento (cultivo) de microrganismos fora do meio natural. Dentre as substâncias que estão na formulação dos meios de cultura semissólidos usados no laboratório, está o ágar, que é o componente que dá consistência ao meio, o tornando semissólido, e permitindo, assim, o trabalho de isolamento das colônias bacterianas (Figura 9). $\mathrm{O}$ 
ágar é misturado aos demais reagentes e colocado nas placas de Petri ou em tubos de ensaio (Figura 10).

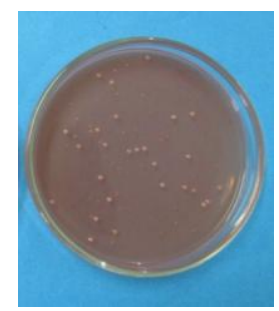

Figura 9 - Placa de Petri com meio de cultura com isolamento de colônias bacterianas

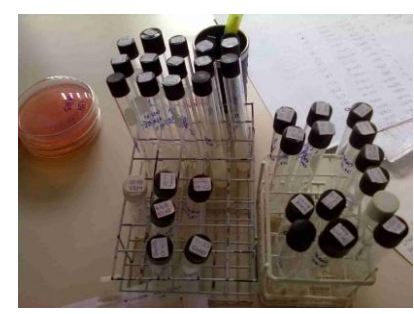

Figura 10 - Tubos de ensaio com meio de cultura com crescimento de massa bacteriana

b) Tratamento: os resíduos semissólidos, antes do descarte, passam pelo tratamento de esterilização em autoclaves, por uma hora a 1,5 atm à $121^{\circ} \mathrm{C}$ (Figura 11), eliminando os microrganismos e deixando o resíduo inócuo. O meio ao sair da autoclave está estéril. Assim, as placas com os meios de cultura são colocadas em panelas de alumínio tampadas com papel Kraft e, após a esterilização, os meios são retirados das placas e vertidos para bombonas de plástico (Figuras 12) para serem descartados no lixo urbano ou doados a agricultores interessados para o aproveitamento em composteiras (Figura 13 a e b).

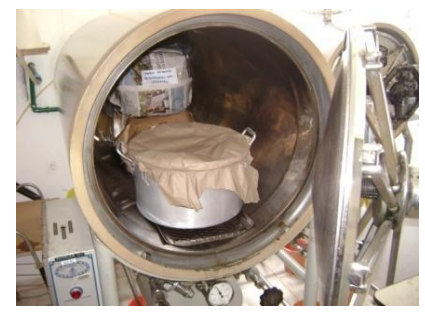

(a)

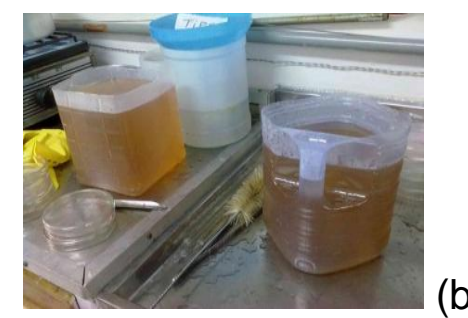



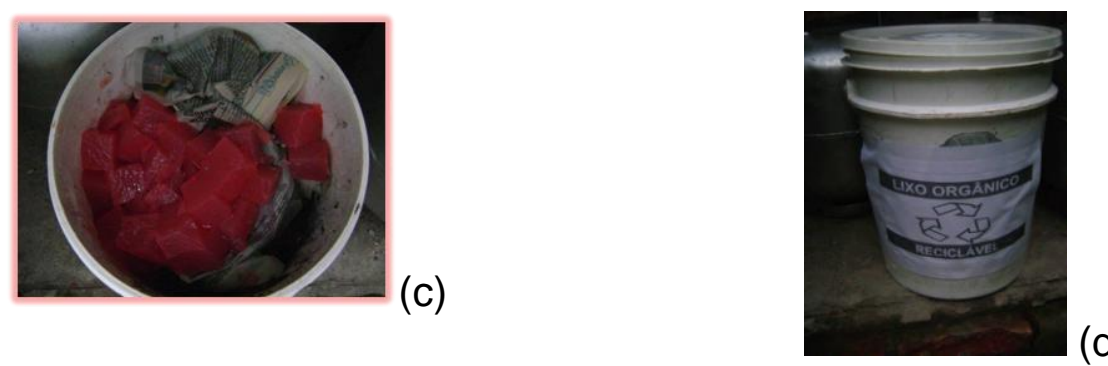

Figura 11 (a) - Autoclave com panela de alumínio com meio de cultura para ser esterilizado;

(b) Bombomas com meio de cultura esterilizado, liquefeito; (c) Interior da bombona para descarte de meios de cultura solidificados para serem doados a agricultores; (d) exterior da bombona com rotulagem de reaproveitamento

Anteriormente, os resíduos, após a esterilização, eram descartados em vaso sanitário. Houve essa modificação por que com o passar do tempo, o meio de cultura pode se depositar nas paredes da rede sanitária causando um entupimento. Além, do mais, essa água vai parar na rede de esgotos e quando chega às estações de tratamento, pode causar uma dificuldade na separação e na purificação da água.

\section{Eficácia do tratamento do material por esterilização através de autoclave}

A esterilização, por umidade e pressão, através da autoclave é o meio mais eficiente para a eliminação de agentes, conforme descrito na Lei Complementar no. 395/97 e Manual de Biossegurança CGVS/SMS/2003 art. 158 ${ }^{6}$. No laboratório, não há trabalhos com agentes patogênicos, mas todo e qualquer resíduo de meio de cultura passa pelo processo de esterilização em autoclave. Às vezes, aparecem placas com fungos ou outros microrganismos (Figura 14 a) com características morfológicas distintas dos rizóbios (contaminantes) que podem ser disseminados no laboratório e comprometer os trabalhos realizados na rotina. Essas placas são levadas à esterilização, $121^{\circ} \mathrm{C}$ por uma hora. Terminado o tempo de esterilização, são retiradas da autoclave, para resfriamento. Após o meio é retirado das "panelas" e vertido em um recipiente plástico - garrafa de água cortada (Figura 14 - b), onde sofre o processo de solidificação do meio de cultura. Posteriormente, esse meio é desenformado (Figura 14 - c) e colocado em sacos plásticos (Figura 14 - c) para ser

\footnotetext{
${ }^{6}$ Essa lei descreve que: "é obrigatória à execução sistemática de teste biológico, ou outro que venha a substituílo, que comprove a eficiência dos equipamentos destinados à esterilização de materiais, o qual deverá ser registrado e assinado pelo responsável técnico".
} 
descartado em lixo orgânico. Segundo a $\mathrm{SMAM}^{7}$, esse tipo de descarte tem que ser feito em lixo orgânico. O meio quando não é descartado em lixo é depositado em uma bombona na área externa do laboratório para ser doado a pequenos agricultores para serem usados em compostagens.
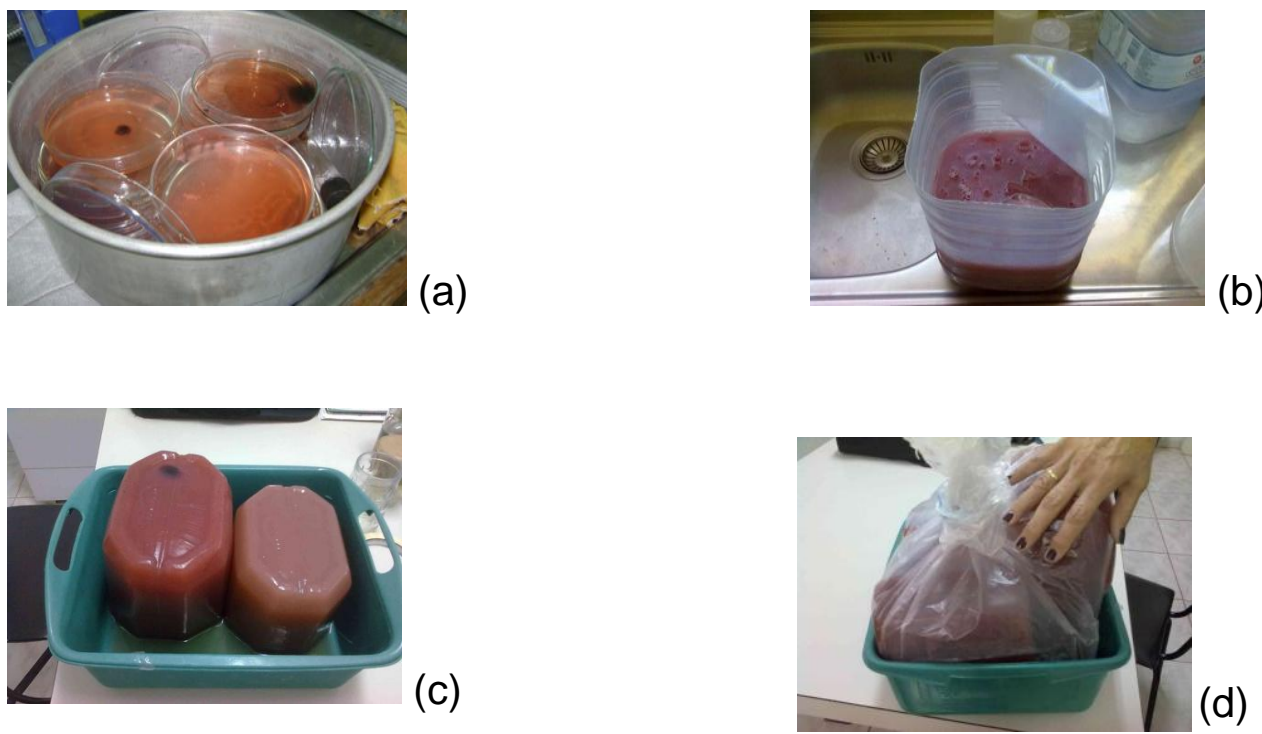

Figura 14 (a) - Placas de Petri com meio de cultura contaminado após o processo de esterilização em autoclave (b) Meio de cultura liquefeito após o processo de autoclavagem; (c) Meio de cultura desenfornando do recipiente plástico, após a solidificação; (d) Meio de cultura solidificado e embalado em saco plástico para ser descartado em lixo orgânico.

\section{Minimização de geração de resíduos no laboratório}

O princípio da minimização é uma tentativa de reduzir a quantidade melhorando a qualidade de resíduos gerados em qualquer atividade exercida pelo homem. Outro aspecto importante é a redução do consumo energético (energia elétrica e gás) além de melhorar a segurança biológica do descarte. No laboratório, o procedimento para minimizar a geração de resíduos semissólidos passou por uma modificação significativa, por conta do consumo de energia e de gás e de redução do risco biológico. O meio de cultura era retirado das placas ou dos tubos de ensaio, colocado em panela de alumínio e fervido até liquefazer o ágar para depois proceder ao descarte. Esse método além de ser dispendioso, não garantia uma total

\footnotetext{
${ }^{7}$ Secretaria de Meio Ambiente do Município de Porto Alegre.
} 
esterilização dos meios de cultura, tendo em vista que além de colônias de rizóbios, podia haver outros microrganismos mais resistentes que, muitas vezes, não são eliminados por esse processo. O processo atual, que é a esterilização em autoclave, é muito mais eficiente, pois a temperatura e o tempo em que o meio de cultura é exposto $\left(121^{\circ} \mathrm{C}\right.$ e por um tempo de uma hora) garantem que as pessoas que manuseiam esse material não fiquem expostas e nem prejudique a saúde.

Segundo artigo 1ำ, parágrafo XII da Resolução CONAMA ํo. 358/05, esta preocupação faz parte de sistema de tratamento de resíduos de serviços de saúde que corresponde a um: "conjunto de unidades, processos e procedimentos que alteram as características físicas, físico-químicas, químicas ou biológicas dos resíduos, podendo promover a sua descaracterização, visando à minimização do risco à saúde pública, a preservação da qualidade do meio ambiente, a segurança e a saúde do trabalhador".

O meio de cultura, após ser autoclavado, pode ser colocado em lixo de resíduos orgânicos (Figura 15) com maior segurança para as pessoas que irão recolhê-lo, que no caso, são os próprios funcionários DMLU.

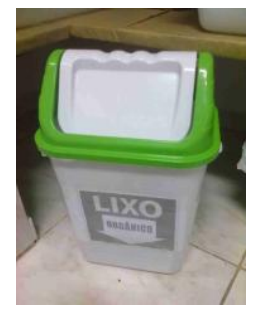

Figura 15 - Recipiente para descarte de resíduos orgânicos

Cabe ressaltar que o meio de cultura serve como matéria orgânica para a compostagem. A compostagem é um método de tratamento de resíduos sólidos que contribui para a redução da quantidade de lixo destinada aos aterros, gerando composto orgânico, que é ótimo condicionador de solos e fonte de nutrientes para as plantas e com grande aceitação do produto para utilização na agricultura.

Em laboratórios de microbiologia clínica, os resíduos de meio de cultura são armazenados em conteiners, segundo artigo $7^{\circ}$ do CONAMA ํㅜ 358/05. No LFBN, as placas Petri e os tubos de ensaio contendo meios de cultura são separados e colocados em bandejas (Figura 16). Pois, quando houver um volume significativo desse material, esse é levado à esterilização. Após esse processo, são descartados 
em lixo comum segundo a Lei Complementar nº 234 /90 - Código de Limpeza Urbana de Porto Alegre.

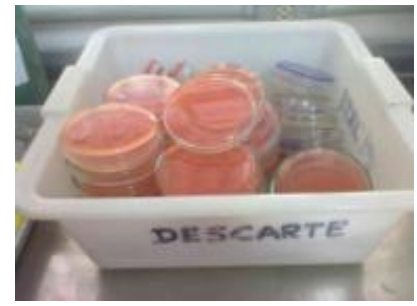

Figura 16 - Bandeja com placas de Petri com meios de cultura para serem esterilizados.

O estudo da alternativa representada pela compostagem mostrou vantagens como à redução do material orgânico para disposição em aterros, aumentando a sua vida útil, além da principal, o aproveitamento como fertilizante. Segundo Narayana (2009), trata-se da melhor alternativa para os países em desenvolvimento. Contudo, a justificativa para a sua baixa utilização tem sido a dificuldade em gerar lucro (HAZRA; GOEL, 2009).

A minimização de resíduos sólidos é entendida como uma maneira de evitar a geração, bem como, recuperar de algum modo o resíduo gerado. O uso de placas Petri de vidro serve como um agente que minimiza a geração de resíduos sólidos, pois quando usadas placas de plástico há uma produção de material, que não pode ser reutilizado nos trabalhos desenvolvidos no LFBN. Caso essas últimas sejam usadas são enviadas para uma unidade de recolhimento Posto de Entrega Voluntária (PEV) de material reciclável, do DMLU, nas proximidades do laboratório (Figura 17) ou são doadas para universidades que reutilizam para outros fins.

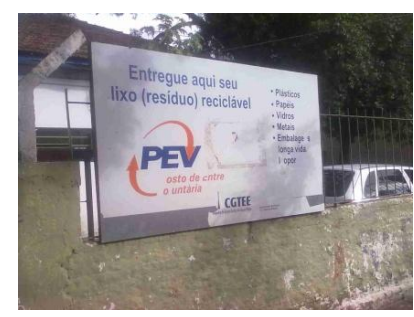

Figura 17 - Posto de Entrega Voluntária (PEV)

As placas de Petri são esterilizadas com os meios de cultura. O meio de cultura é vertido para um recipiente de plástico (Figura 18 - a) e deixado à temperatura ambiente, para resfriamento, solidificação (Figura 18 - b) e depois é descartado (Figura 18 - c). Essas placas são colocadas em balde de 20 litros, é adicionada uma medida - em torno de $100 \mathrm{~mL}$ - de uma solução contendo hipoclorito de sódio a 1 
$\%$, e acrescentado água corrente até a completa cobertura do nível das placas (Figura 18 - d). Elas permanecem mergulhadas nesta solução, por 24 horas.

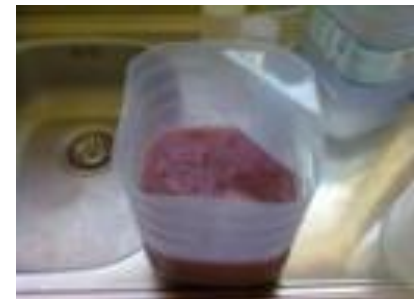

(a)

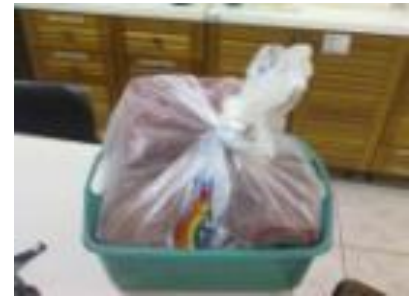

(c)

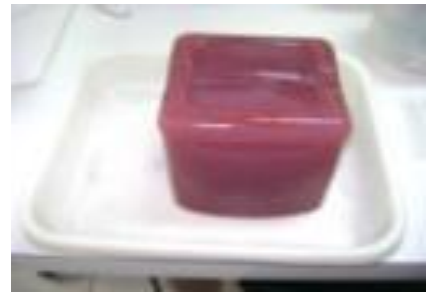

(b)

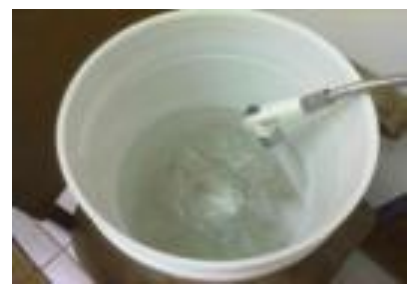

(d)

Figura 18 - Recipiente com o meio de cultura liquefeito (a); meio de cultura solidificado (b); meio de cultura descartado (c); placas emersas em solução de hipoclorito de sódio e água a 1\%.(d)

O gerenciamento inadequado de tais resíduos pode resultar em riscos indesejáveis às comunidades, constituindo-se, ao mesmo tempo, em problema de saúde pública e fator de degradação do meio ambiente.

\section{Descarte de inoculantes líquidos e sólidos}

Quanto ao descarte, os inoculantes líquidos eram descartados em esgoto comum após a diluição com água corrente, sem grandes problemas. Hoje, com o conhecimento de procedimentos buscando uma consciência ecológica e de melhoria ambiental com reutilização e otimização dos recursos, nada mais adequado e politicamente correto que esses produtos sejam reaproveitados. Sendo assim os inoculantes não são mais desperdiçados, pois são armazenados, em garrafas PET, (Figura 19) para serem doados a agricultores interessados, que os utilizam em composteiras. No que dizem respeito às embalagens, estas são destinadas para a reciclagem. 


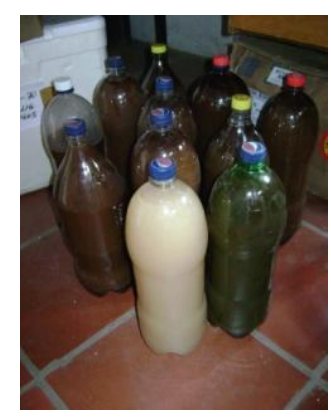

Figura 19 - Garrafas PET com inoculantes

Os inoculantes turfosos, também, são destinados a composteiras ${ }^{8}$, descarte no solo como condicionador ou sofrem um novo processo para o reaproveitamento da turfa ${ }^{9}$ com o propósito de servir de suporte para uma nova produção de inoculante.

Os resíduos do procedimento das análises fiscais dos inoculantes, também, recebem o mesmo tratamento citado para o descarte dos produtos inoculantes.

\section{DISCUSSÃO}

Os resíduos semissólidos, que, um dia, foram meios de cultura muito utilizados nos diversos procedimentos executados no laboratório, passaram por alteração do manejo na hora do descarte, embora da maneira como era feito também fosse correta. A mudança na metodologia do descarte de meios de cultura teve o propósito de evitar um transtorno maior, na questão de poder provocar entupimento da vias sanitárias. Pois, o meio como é uma gelatina (ágar), tem a tendência de aderir e solidificar nas paredes da tubulação sanitária.

Esse manejo dos meios de cultura foi otimizado, porque possibilitou que a forma de descarte após a autoclavagem venha garantir que agentes nocivos tenham sido eliminados. Antes o processo de esterilização por fervura não garantia a eliminação total de microrganismos que poderiam disseminar e comprometer os trabalhos

\footnotetext{
${ }^{8}$ A compostagem é uma forma de tratamento biológico da parcela orgânica do lixo, permitindo uma redução de volume dos resíduos e a transformação destes em técnica importante em razão da composição do lixo urbano do Brasil.

${ }^{9}$ Este processo consiste em retirar o produto dos saches, exposição à irradiação solar para a secagem do material, e diminuição da sobrevivência bacteriana para posterior preparo de novos saches de turfa que serão finalmente esterilizados.
} 
realizados no laboratório.

Como a geração destes resíduos sempre foi uma preocupação dos funcionários, não houve maiores entraves na hora traçar um Plano de Gerenciamento Interno de Resíduos. Com esse plano foi evidenciada uma redução dos resíduos, uma otimização da reutilização de plásticos, vidros e demais materiais dentro do laboratório. Outros exemplos são o reuso do detergente Extran e da água de lavagem dos tips, procurando minimizar o consumo deste bem tão precioso que é a água. Isso vem de encontro com o momento que o mundo vem passando, onde há muita geração de resíduos e pouca aplicabilidade de como reciclá-los.

O laboratório, tendo essa visão, começou a implantar a separação de resíduos e a utilização do resíduo seco, como forma de amenizar a produção de material com vida útil curta. A segregação dos resíduos na fonte geradora é uma "chave" para a coleta seletiva, pois evita a perda de qualidade dos recicláveis e melhora as condições de trabalho dos catadores, viabilizando as etapas seguintes da reciclagem. É também a etapa que exige a adesão da população, que tem de mudar seus hábitos no momento do descarte do lixo.

\section{CONCLUSÃO}

Os resultados deste trabalho mostraram a real situação dos resíduos dentro do Laboratório de Fixação Biológica do Nitrogênio e como eles estão sendo manejados dentro do mesmo. Verificou-se que esforços estão sendo realizados junto à fonte geradora, em especial nas etapas de segregação e acondicionamento dos resíduos semissólidos. O diagnóstico realizado possibilita priorizar as ações a serem executadas, principalmente com relação ao descarte de resíduos considerados críticos, que são os meios de cultura e serve também para balizar planos urgentes de gerenciamento.

Diante destes fatos, o Sistema de Geração de Resíduos sugere que o laboratório estruture um modelo de gerenciamento integrado que leve em conta todas as fases, da geração a destinação final, buscando otimizar continuamente o reaproveitamento, a reciclagem e o compartilhamento da responsabilidade ambiental com os fornecedores de bens e serviços.

Independente desta ação torna-se indispensável, principalmente com o Programa 
Intra-institucional de Educação Ambiental para pesquisadores, técnicos, auxiliares, estagiários e bolsistas, uma maior conscientização dos grandes problemas que atingem nossa Comunidade do entorno. Cabe lembrar que a legislação define como sendo de responsabilidade da fonte geradora o correto manejo, armazenamento, transporte, tratamento e destino final de todos seus resíduos.

Quando terminada a fase de análise, os inoculantes são guardados em um depósito para serem doados a agricultores interessados, que podem utilizar esse como adubo beneficiando a sua propriedade. Essa foi uma solução muito bem acertada, pois esse material não pode ser mandado de volta para fábrica como maneira de descarte. Então para não haver o desperdício de material biológico é aproveitado em processo de compostagem, perfazendo assim uma agricultura sustentável e ecologicamente correta.

Em vista dos resultados aqui apresentados, esta experiência no laboratório demonstrou que ações que buscam implementar inovações em qualquer processo, necessitam do comprometimento de todo o pessoal envolvido na rotina laboratorial e de terceiros que serão os beneficiados com o descarte. O Programa de Gerenciamento de Resíduos foi uma alternativa de custo operacional relativamente baixo com maximização de reutilização de materiais e com um descarte racional de resíduos que vem de encontro com a Gestão da Qualidade. A perspectiva deste trabalho é a contribuição para a solução definitiva da disposição, tratamento, recuperação e reaproveitamento, além do descarte adequado dos resíduos sólidos, semissólidos e líquidos gerados nos laboratórios de ensino, pesquisa e serviços.

A tomada de medidas, no contexto da biossegurança, aliado a economia de recursos, a preservação do meio ambiente, a ética e a responsabilidade poderá garantir mais qualidade de vida no presente e um futuro mais saudável para as próximas gerações. 


\section{REFERÊNCIAS}

ALMEIDA, J.R. de et al. Ciências ambientais.Rio de Janeiro: Thex, 2008. 766 p.

- Perícia ambiental Judicial e securitária: impacto, dano e passivo ambiental. Rio de Janeiro: Thex, 2009. 501 p.

. Gestão ambiental para o desenvolvimento sustentável. Rio de Janeiro:

Thex, 2010, $566 \mathrm{p}$.

ASSOCIAÇÃO BRASILEIRA DE NORMAS TÉCNICAS: ABNT:NBR 10.004 Disponível em: http:// www.aslaa.com.br/legislacoes/NBR\%20n\%2010004-2004.pdf Acesso em: 22 de out. 2010.

ASSUMPÇÃO, L.F.J. Sistema de Gestão Ambiental. Disponível em: http:// www.anvisa.gov.br/legis/resol/2003/rdc/33_03rdc.htm Acesso em: 12 de dez. 2010.

BARROS I.P. Resíduos biológicos nos institutos de medicina legal de Goiás: implicações para os trabalhadores. Disponível em: http//: www.fen.ufg.br/revista/revista8_3/v8n3a02.htm. Acesso em 03 de jan. 2010.

BIBLIOTECA CENTRAL CESAR LATTES. PROGRAMA DE CAPACITAÇÃO DE USUÁRIOS EM INFORMAÇÃO CIENTÍFICA E TECNOLÓGICA: Módulo 4 - Guia de Normalização ABNT para Referências e Citações, 2008. Disponível em: http//: www.bibli.fae.unicamp.br /download/ apostila_abnt.pdf Acesso em: 16 mar.2011

BIGOLIN, Fabiano Teixeira; et al. Avaliação dos resíduos em laboratórios de ensino, pesquisa e extensão do CAMPUS da UFSM. Santa Maria/RS, 2006.

CÂMARA, G.M.S. Inoculação das sementes de soja In: CÂMARA, G.M.S. Soja: tecnologia da produção. Piracicaba: G.M.S. CÂMARA. p.278-293, 1998.

CONAMA no 358/05. Disponível em: http:/l www.mma.gov.br/port/conama/res/res05/res35805.pdfdf. Acesso em: 10 dez. 2010. CUNHA, Carlos Jorge Da. O programa de gerenciamento de resíduos laboratoriais do departamento de química UFPR. Química Nova, Curitiba/PR, vol. 24, №. 3, p.424-427, 2001.

Departamento de Meio Ambiente e Limpeza Urbana (DMLU) Disponível em: http:// www2.porto alegre.rs.gov.br/dmlu/ Acesso em: 07 out. 2010.

GALBIATI, Adriana Farina. O Gerenciamento Integrado de Resíduos Sólidos e a Reciclagem. Disponível em: http:// www.amda.org.br/conteudo/2,43,artigos- 
cientificos.aspx. Acesso em: 25 ago. 2010.

HARZA, Tumpa; GOEL, Sudha. Solid waste management in Kolkata, India: Practices and challenges . Disponível em: http://www.elsevier.com/locate/wasman. Acesso em: 13 abri. 2011.

Instituto Brasileiro de Administração Municipal - IBAM - sob o patrocínio da Secretaria Especial de Desenvolvimento Urbano da Presidência da República SEDU/PR. Gestão Integrada de Resíduos Sólidos - Manual Gerenciamento Integral de Resíduos Sólido. Disponível: http;//www.dominiopublico.gov.br/download/texto/ et000017.pdf.. Acesso em: 03 mai. 2011.

JARDIM, Wilson de Figueiredo. Gerenciamento de resíduos químicos. Disponível em: http://lqa.iqm.unicamp.br/pdf/LivroCap11.PDF. Acesso em: 23 abr. 2010.

LA ROVERE, E. L. et al Manual de Auditoria Ambiental Rio de Janeiro: Qualitymark Editora Ltda 2001.

LEI 12.305/2010. Política Nacional dos Resíduos Sólidos Disponível em: http://www.planalto.gov.br/ccivil_03/_ato2007-2010/2010/lei//12305.htm. Acesso em:

LEI COMPLEMENTAR № 395. Institui o Código Municipal de Saúde do Município de Porto Alegre e dá outras providências (D.O.P.A. 24.04.1997) art.158 e Manual de Biossegurança CGVS/SMS/2003.

LEI COMPLEMENTAR №. 234/90 - Código de limpeza urbana. Disponível em: http://www.camarapoa.

rs.gov.br/biblioteca/integrais/LC234Atualizadaat\%C3\%A9LC602.htm Acesso em 13 abri. 2010.

LEI №. 9.921/93 - Dispõe: sobre a gestão de resíduos sólidos.. Disponível em: http://www.mundoambiente.eng. br/legislação/leiAmbientalRS/L9921.pdf. Acesso em: 15 abri. 2010.

LEITE, B. Z.; PAWLOWSKI, U. Gestão Ambiental: Metodologia de minimização de resíduos. Revista Brasil Alimento, Curitiba, PR, № 14 jul p., 31-36, 2002.

MOURA, L.A. A Qualidade e Gestão Ambiental Editora Oliveira Mendes. Dissertação de Mestrado. Escola de Engenharia de São Carlos da Universidade de São Paulo. São Carlos, 2007. 133 p.

NICOLAZZI, João Augusto. Plano de gerenciamento de resíduos sólidos. 2008.37 p. (Monografia de Curso de Especialização) - Centro de Excelência em Turismo. Universidade de Brasília. Brasília: 2008. 
OLIVEIRA. F.A. L. Direto Municipal Sanitário: uma proposta legal para gestão integrada de resíduos sólidos no município de Belém. 2000. 469 p.(Mestrado em Direito) - Centro de Ciências Jurídicas, Universidade Federal do Pará. Belém, 2000. Politica Nacional de Gerenciamento de Resíduos Sólidos Urbanos. Disponível em: http:// www.webartigos.com/articles/60186/1/Artigo A. Acesso em: 02 out. 2010. Resíduos sólidos e lixo hospitalar: uma discussão ética. Disponível em: http:// www.scielosp.org/scielo.php?pid=S0102-

311X1995000200015\&script=sci_abstract\&tlng=enen. Acesso em:22 de fev 2011.

SANTO, G.O.; SILVA, L.F.F. Os significados do lixo para garis e catadores de Fortaleza, Ceará. Ciência e Saúde Coletiva 297/2008. Disponível em: http://www.cienciaesaudecoletiva.com.br/artigos/artigo__ int.php?id_artigo=3041 Acesso em: 15 dez. 2010.

Secretaria do Meio Ambiente (SMAM) Disponível em: http://www2.portoalegre.rs.gov.br/smam/ Acesso em: 02 out. 2010. Segurança de trabalho. Disponível em: http:// www.blogsegurancadotrabalho.com.br/2010/01/coleta-seletiva-de-lixo.html Acesso em: 25 abri. 2011.

SILVA, Carlos Ernando da; HOPPE, Alessandro Eduardo. Diagnóstico de resíduos de serviço de saúde no interior do Rio grande do Sul. Revista Engenharia Sanitária Ambiental, vol.10, ํ‥ 2, p. 146-151.

SILVA, Natércia de Nascimento Oliveira; NASCIMENTO, Elimar Pinheiro do. Gestão Ambiental Empresarial (Curso de Especialização em Turismo - Centro de Excelência em Turismo, Universidade de Brasília. Goiânia: 2007, 58p.

SOUZA, A. R.; PASQUETTO, A. Gerenciamento dos resíduos de serviço de saúde dos laboratórios biológicos da área v da ucg. Goiânia, 2006/2 Departamento de Engenharia. Engenharia Ambiental: Universidade Católica de Goiás, Goiânia, 2006. Disponível em: www.ucg.br/ucg/prope/cpgss Acesso em: 10 de abri. 2011.

ZANETI, ICBB. As Sobras da Modernidade. O Sistema de Gestão de Resíduos Sólidos em Porto Alegre. Porto Alegre, RS. 2006 